\title{
SOCIALIAI ATSAKINGĄ VARTOJIMĄ LEMIANTYS VEIKSNIAI IR RIBOJANČIOS PRIEŽASTYS
}

\author{
Vytautas Juščius ${ }^{1}$, Deimanté Maliauskaité2 \\ Klaipèdos universitetas (Lietuva)
}

\begin{abstract}
ANOTACIJA
Socialiai atsakingo vartojimo tema tampa vis svarbesnè ne tik verslui, bet ir visuomenei. Neigiamos ịmonių veiklos pasekmès ir perdètas vartojimo sureikšminimas paskatino darnaus vystymosi šalininkų aktyvumą ir socialiai atsakingo vartojimo tyrimus. Siekiama nustatyti pagrindinius veiksnius, lemiančius socialiai atsakingą vartojimą ir priežastis, dèl kurių vartotojai nesirenka socialiai atsakingų ịmonių prekių. Straipsnyje akcentuojami du socialiai atsakingo vartojimo matmenys: aplinkos matmuo (vengimas pirkti produktus, kurie neigiamai veikia aplinką) ir visuomenès matmuo (vengimas pirkti tų įmonių produktus, kurie daro neigiamą poveikị visuomenės gerovei). Atlikus lyginamają mokslinès literatūros analizę nustatyta, kad įmonių socialinès atsakomybės (ĮSA) kriterijus nèra dominuojantis priimant pirkimo sprendimus, todèl İSA yra mažiau svarbi nei kiti pirkimo kriterijai, tokie kaip kaina, kokybė, patikimumas, klientų aptarnavimas, produktų garantijos terminas ir kt. Pagrindinės socialiai atsakingą vartojimą ribojančios priežastys yra klaidingas vartotojų požiūris, menkas veiksmingumo suvokimas, pajamų, išsilavinimo ir informacijos trūkumas.

PAGRINDINIAI ŽODŽIAI: įmoniu socialine atsakomybè, socialiai atsakingas vartojimas, vartotojo elgsena.
\end{abstract}

JEL KLASIFIKACIJA: M140, M310, L200, A130.

DOI: http://dx.doi.org/10.15181/rfds.v14i3.859

Ivadas

Išprusę gyventojai vis daugiau dėmesio kreipia ị vartojimo ekologines ir socialines pasekmes. Neigiami vartojimo padariniai aplinkai ir pačiai visuomenei skatina žmones atsakingiau vartoti ir atidžiau rinktis perkamas prekes. Verslo įmonès, kurios stengiasi tausoti gamtos išteklius, siekia sumažinti žalingą gamybos poveikị gamtai, rūpinasi personalo darbo sąlygų gerinimu, moka darbuotojams adekvatų atlygit, sulaukia pelnyto vartotojų palankumo.

Tyrimo problema. Nors vartotojai vis labiau domisi įmonių socialine atsakomybe, tyrimai atskleidžia skirtumą tarp vartotojų domèjimosi įmonių socialine atsakomybe ir šios informacijos panaudojimo priimant sprendimą pirkti ar ne tam tikrą produktą (Devinney et al., 2006; Boulstridge, Carrigan, 2000; Smith, 2007; Oberseder, et. al., 2011; Valor, 2005; Castaldo et al., 2009; D’Astous, Legendre, 2009; Bray et al., 2011; Kozar, Connell, 2013; Adomavičiūtè, 2013). Galima teigti, kad ši situacija yra paradoksali: nors vartotojai nori, kad įmonès vykdytų socialiai atsakingą veiklą, tačiau socialinės atsakomybės kriterijus ne visada tampa

$1 \quad$ Vytautas Juščius - Klaipėdos universiteto Ekonomikos katedros vedejjas. Moksliniai interesai: globalizacija, įmonių socialinè atsakomybè

El. paštas: ek.smf@ku.lt

Tel.: +37046398677

2 Deimantė Maliauskaitė - UAB „Step Forward Ortopedija“ direktorè. Moksliniai interesai: vartotojų elgsena, immonių socialiné atsakomybé, ekologija ir medicina.

El. paštas: deimante.maliauskaite@gmail.com

Tel.: +370679022 77 
pirmaeiliu veiksniu renkantis prekes. Neišskirti svarbiausi veiksniai, lemiantys socialiai atsakingą vartojimą, neišryškintos priežastys, ribojančios socialiai atsakingų įmonių prekių pasirinkimą.

Tyrimo objektas - socialiai atsakingas vartojimas.

Tyrimo tikslas: identifikuoti svarbiausius veiksnius, lemiančius socialiai atsakingą vartojimą, išskirti pagrindines priežastis, kodèl vartotojai nesirenka socialiai atsakingų įmonių prekių.

Tyrimo uždaviniai:

- apibrèžti socialiai atsakingo vartojimo matmenis;

- identifikuoti socialiai atsakingą vartojimą lemiančius veiksnius;

- išskirti socialiai atsakingą vartojimą ribojančias priežastis.

Tyrimo metodai: lyginamoji mokslinès literatūros analizè ir sintezè, sisteminimas, apibendrinimas.

\section{Socialiai atsakingo vartojimo matmenys}

Vartotojų socialinė atsakomybė apibrèžiama kaip sąmoningas ir apgalvotas vartojimo pasirinkimas, besiremiantis asmeniniais ir moraliniais ịsitikinimais. Jis apima du pagrindinius komponentus: „Etinį, susijusị su socialinių įmonės produktų ir verslo procesų komponentų svarba, bei vartotojišką, kuris reiškia, kad vartotojai su savo pageidavimais ir norais iš dalies atsakingi už didejjančią etinių ir socialinių veiksnių ịtaką، (Devinney et al., 2006: 3).

Atsakingas vartojimas gali būti apibrèžiamas ir kaip „sąžiningas, žaliasis, tvarus, racionalus, etiškas vartojimas. Sąžiningas vartojimas siejamas su vartojimo poveikiu; žaliasis vartojimas - su siekiu apsaugoti gamtą; tvarus vartojimas - su išteklių išsaugojimu; racionalus vartojimas - su minimaliu suvartojimo kiekiu; atsakingas vartojimas - su žalos vengimu ir apima visas minètas kategorijas“ (Fontenelle, 2010: 266). N. C. Smith taip pat tapatina sąmoningą, etišką, žaliaji vartojimą, nes idejja iš esmè ta pati: „Vartotojai domisi imonių atsakomybe, kuri paveiks jų pirkimo sprendimus bei vartojimo elgseną ir paskatins ịmonès socialinę bei aplinkosauginę atsakomybę" (Smith, 2007: 4). Nors minèti autoriai socialiai atsakingą ir etišką vartojimą laiko sinonimais, šios kategorijos netapačios. Nors socialiai atsakingas vartojimas remiasi visuomenèje nusistovejusiomis vertybėmis, jis negali būti tapatinamas su etišku vartojimu. Neetiško vartojimo pavyzdžiai gali būti nelegalus CD kopijavimas ar melavimas apie vaiko amžių, siekiant mokèti mažesnę kainą už bilietą. Socialiai sąmoningas elgesys, nors gali būti motyvuotas grynai nesavanaudiškais norais, tačiau nauda visuomenei apims ir naudą vartotojui. Taigi socialiai sąmoningas elgesys vienu metu gali būti motyvuojamas tiek asmeninių, tiek ir socialinių interesų. Etiškas vartojimas labiau susijęs su sąžiningu vartotojo elgesiu, o ne pirkimu, kuris pagrịstas socialiniu kriterijumi. Vis dèlto, nors socialiai atsakingas ir etiškas vartojimas nèra visiškai tapatūs, jie iš dalies sutampa. Tai pastebẻjo ir A. Francois-Lecompte, J. A. Roberts, tyrinėdami vartotojų elgesị Prancūzijoje (Francois-Lecompte, Roberts, 2006).

Remiantis mokslinès literatūros analize, skiriami du socialiai atsakingo vartojimo matmenys: aplinkos matmuo (vengimas pirkti produktus, kurie neigiamai veikia aplinką) ir visuomenès matmuo (vengimas pirkti tų ịmonių produktus, kurie daro neigiamą poveikị visuomenės gerovei). Be to, socialiai atsakingą vartojimą galima susieti su:

- $\quad$ įmonès elgesiu (atsisakymas pirkti iš įmonių, kurių elgesys laikomas neatsakingu);

- pirkimu dèl tam tikros priežasties (produktai, kurių kainos dalis teks geram tikslui);

- noru padèti smulkiajam verslui (padèti mažų parduotuvių savininkams išgyventi, ne viską perkant prekybos centruose);

- požiūriu ị produktų kilmès šalị (pirmenybès teikimas produktams iš savo šalies);

- vartojimo mažinimu (vartotojas vengia „suvartoti per daug“) (Gonzalez, Korchia, 2009: 29).

Šiuos matmenis gali papildyti ir kiti aspektai: produktų perdirbimas, draugiški aplinkai vartojimo būdai (naudojimasis viešuoju transportu, pirmenybės teikimas produktams, kurie neteršia aplinkos) ir kiti.

Naujausi vartotojų elgsenos tyrimai atskleidžia, kad vartotojai labiausiai save identifikuoja kaip aplinkai draugišką vartotoją (67,4 \%), šiek tiek mažiau - kaip socialiai atsakingą (48,6 \%) ar etišką (44,6 \%) (Roux, Nantel, 2012). Galima daryti išvadą, kad vartotojai labiausiai rūpinasi aplinkosauga, nes yra aišku, kaip 
galima prisidèti prie neigiamo poveikio aplinkai mažinimo. Vèliau vartotojai prisiima socialinę atsakomybę, kuri apima platesnị veiksnių spektrą: žmogaus, gyvūnų teises, etiką, kuri yra abstrakčiausia, nes apima vartotojų veiksmų moralę. Taigi, nors socialinè, etinė ir aplinkosauginè atsakomybė glaudžiai tarpusavyje susijusios kategorijos, jos atsakingą vartojimą atskleidžia skirtingais aspektais (1 pav.).

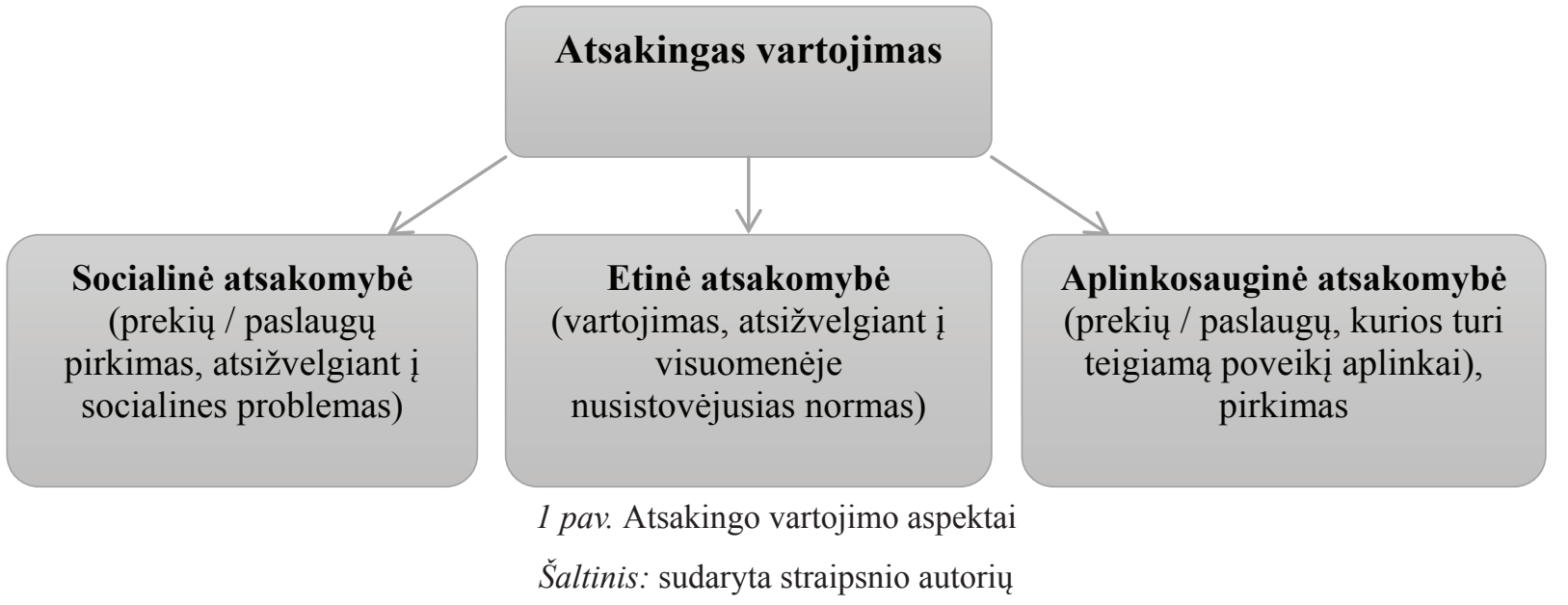

Apibūdinant socialiai atsakingą vartojimą vartojamos skirtingos sąvokos, tačiau jų pagrindas yra tas pats: racionalus ir veiksmingas išteklių naudojimas, atsižvelgiant ị poveikį visuomenei bei aplinkai.

\section{Socialiai atsakingą vartojimą lemiantys veiksniai}

Didejjantis žemės gyventojų skaičius neabejotinai veikia biologinę ịvairovę ir žmonijos ekologinị pèdsaką ${ }^{3}$. Kiekvieno asmens vartojamoms prekèms ir paslaugoms pagaminti sunaudoti ištekliai bei sukurtos atliekos lemia ekologinio pėdsako dydị (Living planet report 2012, 2012: 52). Pasaulyje stipreja perteklinio vartojimo tendencija: $2014 \mathrm{~m}$. statistiniai duomenys rodo, kad gamtos išteklių sunaudojama $\sim 1,5$ kartus daugiau nei žemė jų gali atnaujinti (Living planet report 2014, 2014: 32).

Akivaizdu, kad toks intensyvus žemės išteklių vartojimas kartu su augančia žmonių populiacija sukelia neigiamas pasekmes: klimato kaitą, maisto, vandens ir energijos trūkumus, konfliktus dèl išteklių ir t. t. Šalies ekologinis pėdsakas priklauso nuo suvartojamų prekių ir paslaugų kiekio bei joms sunaudojamų išteklių ir generuojamų atliekų. Pavyzdžiui, jei visa žmonija gyventų kaip vidutinis Indonezijos gyventojas, būtų sunaudojama tik du trečdaliai planetos ištekliu, jei visi gyventų kaip vidutinis Argentinos pilietis, žmonijai reikètų daugiau nei pusès papildomos planetos, o jei visi gyventų kaip vidutinis JAV gyventojas, reikètų keturių tokių kaip Žemė planetų, norint atkurti žmonių padarytą ir daromą žalą gamtai (Living planet report 2012, 2012: 43).

Minètų neigiamų vartojimo pasekmių negalima sumažinti be vartotojų požiūrio ir elgesio pokyčių. Socialiai atsakingas vartojimas prasideda nuo problemos suvokimo ir priklauso nuo įvairių veiksnių. Planuojamo elgesio teorija teigia, kad individų įsitikinimai grindžiami požiūriu ir elgesio ketinimais. Vartotojų ịsitikinimus formuoja dviejų tipų veiksniai: „Patikimos informacijos šaltiniai ir socialiniai veiksniai, įskaitant bendraamžių, šeimos, religijos įtaką“" (Bray et al., 2011: 599).

Viešasis sektorius, kultūros, sveikatos, švietimo institucijos, siekdamos vartotojams suteikti kokybiškas paslaugas ima taikyti rinkos ekonomikos taisykles ir igyvendina ị vartotojus orientuoto valdymo principus. I vartotojų kategoriją įtraukiami net teatro lankytojai, pacientai ir universitetų studentai. Kinta vartojimo produktų simbolinè vertè, prekès vartotojiškoje visuomenèje atlieka ne tik tiesioginę poreikių tenkinimo, bet ir komunikacijos funkciją. Tam tikrų produktų turẻjimas ar paslaugų vartojimas reiškia narystę tam tikrose

3 Ekologinis pėdsakas nusako, kiek žemės ar vandens individai sunaudoja vartojimui ar vartojimo prekėms pagaminti, kiek žemės ploto reikia, kad būtų atnaujinti žmonių sunaudoti ištekliai ir neutralizuotos sukurtos atliekos. Paprastai matuojamas pasaulio hektarais. 
socialinėse grupėse arba priešingai - nepriklausymą joms ir atskleidžia santykius tarp žmonių bei jų sudaiktinimą. Išskirtinių produktų turejjimas suteikia individui galimybę atskleisti savo vertybes (Ozkan, 2009).

Empiriniai tyrimai patvirtina, kad vartotojų apsisprendimą ịsigyti prekę ne visada lemia socialinis kriterijus (Valor, 2005), o kaina, kokybė ir teikiama nauda išlieka svarbiausi kriterijai priimant sprendimą pirkti (Boulstridge, 2000). Tai rodo, kad sprendimas priimamas dèl asmeninių, o ne dèl socialinių priežasčių. Galima teigti, kad vartotojai labiau motyvuojami savanaudiškų, o ne visuomenès interesų, todèl socialiai atsakingas vartojimas galimas tik tada, kai teiks naudą vartotojams. Dèl to vartotojai mano, kad bendrovès turi užsiimti socialiai atsakinga veikla, tačiau jie patys nenori mokèti didesnès kainos už socialiai atsakingų imonių pagamintas prekes (D’Astous, Legendre, 2009). Nors kai kurie vartotojai gali mokèti daugiau už socialiai atsakingai pagamintus produktus, jie tai darys tik tada, kai tų produktų savybės patenkins jų poreikius. Kitaip tariant, kai pateikiami du alternatyvūs produktai ta pačia kaina (vienas jų pagamintas laikantis socialinės atsakomybės reikalavimų, bet prastai atlieka funkcijas, kitas pagamintas laikantis ne visų socialinės atsakomybės reikalavimų, bet puikiai atlieka funkcijas), vartotojai beveik visada teiks prioritetą produktui, kuris atitiks keliamus funkcinius reikalavimus.

Socialiai atsakingų įmonių produktus vartotojai renkasi tik tada, kai tenkina prekès kainos ir kokybès santykis. Vartotojai už socialiai atsakingai pagamintus produktus daugiau mokètų tik tada, jei produkto funkcinės savybės tenkintų jų poreikius, nes beveik visada renkasi prekę, kuri pasižymi prastesniais socialiniais ir geresniais funkciniais požymiais. Austrų mokslininkai atliko giluminius interviu su 22-iem Vakarų Europos šalių respondentais, kurie patvirtino, kad İSA yra mažiau svarbus nei kiti pirkimo kriterijai, tokie kaip kaina, kokybė, ženklas, kilmès šalis ir kiti (Oberseder et al., 2011: 453). Vartotojai linkę pirkti socialiai atsakingus produktus, kurie ne tik nekainuoja brangiau, yra geros kokybès, bet ir nereikalauja specialiu pirkimo pastangų (Bray et al., 2011).

V. Pedregal ir N. Ozcaglar-Toulouse atliktas diskusijų grupių tyrimas atskleidè, kad dažnam vartotojui svarbesnė maisto produktų ar kitų nuolat naudojamų produktų kaina nei socialinės vertybės. Būtina pastebèti, kad sąžiningos prekybos (angl. Fair trade) prekès vidutiniškai 10-20\% brangesnès nei alternatyvūs tos pačios kokybės produktai, o vartotojai, kurie vis dèlto ryžtasi mokèti daugiau, pavyzdžiui, už sąžiningos prekybos prekes, tikisi gauti geresni produktą, priešingu atveju jaučiasi nuvilti (Pedregal, Ozcaglar-Toulouse, 2011). Minètų autorių tyrimas parodè, kad keisti vartojimo ịpročius skatina naujienos (ypač neigiamos), priverčiančios susimąstyti apie socialines problemas. Nustatyta, kad neigiama informacija labiau skatina vartotojus keisti blogus vartojimo ịpročius bei turi didesnę ịtaką pirkimo sprendimams nei teigiama (Bray et al., 2011).

Vartotojų sprendimą pirkti vieną ar kitą prekę ar jos nepirkti lemia eilè vidinių ir išorinių veiksnių. Vartotojų elgsenos tyrimuose vienu populiariausių išlieka dar septintojo dešimtmečio pabaigoje J. Engel, D. Kollat ir R. Blackwell sukurtas vartotojų sprendimo prièmimo modelis. Jame išskirti penki sprendimo pirkti / nepirkti etapai: problemos pripažinimo, informacijos paieškos, alternatyvų įvertinimo, pirkimo sprendimo ir elgesio po pirkimo (Engel et al., 1968).

Taikant šį modelị nustatyta, kad ,individo pažiūros, poreikių ịvertinimas, informacijos paieška lemia elgesio ketinimus ir galiausiai patị elgesį“ (Schaefer et al., 2005: 82). Reikia pastebėti, kad socialiai atsakingi vartotojai paprastai ieško daugiau informacijos ir yra atsargesni pirkėjai. „Tik aktyvūs informacijos ieškotojai gali keisti mėgstamą produktą kitu, kuris yra mažiau veiksmingas, bet saugesnis aplinkai“ (Auger et al., 2003: 284). Tokie vartotojai priimdami sprendimus dažnai ieško ir kompromiso tarp vertybių ir poreikių. Pavyzdžiui, ,pirkdami ekologiškus maisto produktus vartotojai gali pasirinkti brangesnį, bet naudingesni sveikatai produktą“" (Freestone et al., 2008: 447). Ir priešingai, J. M. Kozar ir kt. atliktas tyrimas atskleidè, kad vartotojai, kuriems suteikiama daugiau informacijos apie socialines ir aplinkosaugos problemas, labiau linkę priimti atsakingus pirkimo sprendimus (Kozar et al., 2013). Taigi sprendimas, kuri priims vartotojas, norintis įsigyti prekę, priklauso ne tik nuo jo paties pastangų, bet ir nuo ji pasiekiančios informacijos apie lokalias ir globalias visuomenès problemas.

Socialiai atsakingų vartotojų pasirinkimą lemia ir veiksmingumo suvokimas, kuris suprantamas kaip gebejjimas daryti ịtaką didesnio masto problemos sprendimui, priklausančiam nuo vartojimo pasirinkimo (Cor- 
nelissen et al., 2011). Jei vartotojai jaučia, kad jų sprendimas gali ką nors pakeisti, jie bus labiau linkę elgtis socialiai atsakingai. Viename iš vartotojų veiksmingumo tyrimų nustatyta, kad galëjimo pakeisti situaciją jausmas buvo beveik šešis kartus svarbesnis nei abstraktus susirūpinimas dèl aplinkos (Cotte et al., 2009). Taigi vartotojo supratimas, kad kiekvienas jo pirkinys reikšmingas siekiant išspręsti tam tikrą socialinę ar aplinkosauginę problemą, yra svarbus pradinis žingsnis skatinant visuomenės socialiai atsakingą vartojimą.

Sprendimui ịsigyti prekę ịtaką daro ir bendrovès patrauklumas, kuris priklauso nuo jos gebejjimo patenkinti bent vieną iš trijų pagrindinių vartotojų individualumo poreikių:

- tęstinumo (poreikis atpažinti panašų ị savo bendrovès identitetą);

- išskirtinumo (poreikis atskirti save nuo kitų socialinių kontekstų ir susitapatinti su įmone, kuri turi savitą kultūrą, strategiją, struktūrą ir t. t.);

- $\quad$ stiprinimo (poreikis jausti sąsają su bendrove, kurios tapatybė yra patraukli, taip stiprinant savo savigarbą, imant labiau save vertinti) (Marin et al., 2007).

Suinteresuotosios grupès vertina įmonių siekị ịtvirtinti atsakingumą ir ịkūnyti savybes, kuriomis jos tiki. Nustatyta, kad vartotojų sprendimams svarbios ir produktų reikšmès (Papaoikonomou et al., 2011). Prekèms reikšmę suteikia reklama, paplitusi mada, įžymybès, žodis iš lūpų i lūpas ir žiniasklaida, referentinių grupių informacija. Vartotojai, priimdami sprendimus įsigyti konkrečias prekes, igyja ir šių prekių reikšmes, iš kurių formuoja savo tapatybę.

\section{Socialiai atsakingą vartojimą ribojančios priežastys}

Vartojimas yra socialiai neatsakingas, jei:

- pirkimas grindžiamas tik pagrindiniais kriterijais: kainos, kokybèd, patogumo ir kt.;

- vartotojai nepakankamai informuoti ir sunku gauti informacijos apie İSA.

Vartotojai perka atsakingai, jeigu jie turi informacijos apie įmonès poveikị žmonių socialinei gerovei, tačiau dažnai jiems tokios informacijos nepakanka (Valor, 2007), o jos stoka yra viena pagrindinių kliūčių, trukdančių lavinti atsakingo vartojimo įpročius (Durif et al., 2010).

Verslininkai socialinès atsakomybės ataskaitose suinteresuotosioms grupėms apie savo socialinę ir aplinkosauginę veiklą stengiasi pateikti reikšmingą ir patikimą informaciją. Tačiau vartotojams dažnai sunku šią informaciją panaudoti apsisprendžiant pirkti. Eiliniai vartotojai, svarstydami alternatyvas, retai tikslingai ieško informacijos apie İSA, o ataskaitos prekybos vietose neviešinamos. Be to, ataskaitose duomenys neretai būna pateikti gana sudėtingu pavidalu, juos suprasti nepaprasta.

Efektyvus būdas informuoti vartotojus apie gamintojų atsakingumą yra prekių ženklai ir specialios etiketès. Vien Europoje yra daugiau nei 240 skirtingų etikečių, kurios užtikrina, kad viena ar kita socialinès atsakomybės sritis buvo patikrinta (pvz., aplinkos su ekologiniu ženklu ar vaikų darbo su „Rugmark“ etikete) (Valor, 2007: 320). Skirtingos suinteresuotosios grupės yra jautrios skirtingiems İSA aspektams, dèl to net ir ta pati sritis (pvz., darbo teisès) turi daugiau nei vieną etiketę. Dėl didelio etikečių skaičiaus vartotojai jaučiasi sutrikę. Viena bendra etiketė supaprastintų pasirinkimą ir prisidètų prie socialinès gerovès užtikrinimo.

Dar viena socialiai atsakingą vartojimą ribojanti priežastis gali būti vartotojo veiksmų efektyvumo laipsnis. Jei vartotojo pirkinys prisideda prie tam tikros problemos sprendimo, tai didina jo motyvaciją atsakingai vartoti. Galima teigti, kad vartotojų naudojami informacijos šaltiniai tam tikra prasme turi ịtakos suvokiamam kiekvieno sprendimo efektyvumo laipsniui. Tradiciškai žiniasklaida daugiau dèmesio skiria intrigai nei problemos sprendimui. Didžioji dalis pranešimų apie I̦SA dèmesị sutelkia ties gamta ar visuomenei padaryta žala, o ne ties jos priežastimis ar būdais, kaip būtų galima spręsti iškilusią problemą. Vartotojai, gaunantys papildomos informacijos per formaluji (pvz., universiteto programos) ar neformalųji (pvz., NVO seminarai ar kampanijos) švietimą, mokslo leidinius, skatinami atsakingai pirkti. Švietimas yra svarbus, norint pakeisti vartojimo ịpročius ir skatinti vartotojų sąmoningumą (Kozar, 2013). 
Socialiai atsakingas vartojimas gali sukelti ne tik papildomų išlaidų, bet ir papildomų nepatogumų vartotojams. Suprantama, kad ne visi vartotojai yra pasirengę aukoti savo patogumą ir keisti gyvenimo būdą dèl bendros gerovès. Mokslininkai skiria tris pagrindines priežastis, kurias įvardija vartotojai, norèdami pateisinti savo neetišką elgesí, ir kurios neskatina socialiai atsakingo vartojimo:

- ekonominio racionalumo: vartotojai mano, kad socialiai atsakingas vartojimas yra brangus, o kaina ir kokybė yra svarbiau nei socialiai atsakingi požymiai. Pavyzdžiui, vartotojai pripažịsta, kad jie perka klastotes, nes originalaus prekès ženklo gaminio kaina yra pernelyg didelè;

- ekonominio augimo realybès: vartotojai mano, kad ekonominè šalių plètra pateisina neetišką elgesi ir šalys, siekiančios gauti didesnès naudos iš ekonominio augimo bei norinčios pasiekti aukštesnị pragyvenimo lygị, turi nustumti ị šalị etinius ir moralinius siekius. Manoma, kad susirūpinimas socialiniais ir aplinkosauginiais klausimais stabdo ekonomikos plètrą. Perdètas ekonominio augimo sureikšminimas ir jo neigiamo poveikio ignoravimas neskatina vartotojų ir gamintojų atsakingumo iniciatyvų.

- priklausomybè nuo vyriausybès: vartotojai linkę manyti, kad, jei būtų didelių problemų, vyriausybė imtųsi tam tikrų veiksmų. Vartotojai taip pat mano, kad ten, kur nėra įstatymų, reglamentuojančių socialiai neatsakingus veiksmus, jų elgesys yra teisètas ir jie negali būti dèl to kaltinami. Be to, vyriausybės neveiklumas rodo, kad nėa priežasčių, verčiančių susirūpinti (D’Astous et al., 2009).

Jau minèta, kad vartotojo finansiniai ištekliai yra būtina sąlyga, leidžianti İSA taikyti kaip pirkimo kriterijų. Tačiau kita vertus, kaina dažnai yra tik pasiteisinimas, kodẻl neperkami socialiai atsakingų ịmonių produktai. Dažnai vartotojai mano, kad socialiai atsakingų įmonių produktai yra brangesni nei alternatyvūs. Tam tikrais atvejais, pavyzdžiui, sąžiningos prekybos produktams, šis teiginys gali būti taikomas. Tačiau yra daug produktų, kuriuos siūlo socialiai atsakingos įmonès ne didesne nei kitų gamintojų kaina. Vartotojai dažnai mano, kad tokių produktų negali sau leisti dèl klaidingai ịvertintos kainos.

Taigi socialiai atsakingas vartojimas yra kompleksinis procesas, kuris skatina vartotojus atsižvelgti ne tik i prekių kainą, bet ir ị vartojimo pasekmes. Tyrimais nustatyta, kad vartotojai dažnai skeptiškai žiūri ị ịmonių socialinès atsakomybès deklaracijas ir vertina jas kaip nesą̌̌iningą rinkodarą, kuri naudojasi vartotojų patiklumu ir taip tik didina produktų kainas (Bray et al., 2011). Toks vartotojų cinizmas susijęs su informacijos apie etiškos praktikos naudą trūkumu ir pertekline informacija apie neetišką praktiką. Dviprasmiška informacija sukelia vartotojų nuostatų painiavą ir daro juos pažeidžiamus.

\section{Išvados}

Analizuojant socialiai atsakingą vartojimą galima skirti du matmenys: aplinkos matmenị (vengimas pirkti produktus, kurie neigiamai veikia aplinką) ir visuomenès matmenị (vengimas pirkti tų ịmonių produktus, kurie daro neigiamą poveikị visuomenès gerovei). Šiuos matmenis gali papildyti ir kiti aspektai: produktų perdirbimas, draugiški aplinkai vartojimo būdai (naudojimasis viešuoju transportu, pirmenybès teikimas aplinkos neteršiantiems produktams) ir kiti. Vartotojų elgsenoje nustatyta tam tikra šių matmenų subordinacija: pradiniame etape vartotojai labiausiai linkę rūpintis aplinkosauga, nes teigiami tokio elgesio rezultatai labiau apčiuopiami. Vèliau vartotojai imasi socialinès atsakomybès, kuri apima platesnị veiksnių spektrą bei etiką, kuri yra abstrakčiausia, nes apima vartotojų veiksmų moralę. Nors socialinė, etinė ir aplinkosauginė atsakomybė yra glaudžiai tarpusavyje susijusios kategorijos, jos atsakingą vartojimą atskleidžia skirtingais aspektais.

Vartotojų apsisprendimas perkant prekes labiau pagrịstas savanaudiškais nei visuomenės interesais, todèl socialiai atsakingas vartojimas motyvuojamas tada, kai vartotojai įžvelgia naudą sau. Vartotojai beveik visada teikia prioritetą produktams, pasižymintiems geresniais funkciniais požymiais. Nors vartotojams svarbi İSA, lemiamu konkrečios įmonès produkto pasirinkimo kriterijumi išlieka prekės kainos ir kokybės santykis. Vartotojai prioritetą dažnai teikia tiems produktams, kurie yra ne prastesnès kokybès, ne aukštesnès kainos nei analogiškos prekès, o jų pirkimas nereikalauja specialių pastangų (t. y. papildomų informacijos, sąnaudų, 
laiko ir kt.). Remiantis lyginamaja mokslinès literatūros analize, galima nustatyti šiuos socialiai atsakingą vartojimą lemiančius veiksnius: bendraamžių, šeimos, religijos įtaka; kaina, kokybė ir teikiama nauda; galimybė išreikšti savo nuostatas ir vertybes; socialiai atsakingų produktų prieinamumas; gamintojų patrauklumas; aukštas veiksmingumo suvokimas, t. y. gebėjimas daryti ịtaką didesnio masto problemos sprendimui atsakingai vartojant.

Pagrindinès socialiai atsakingą vartojimą ribojančios priežastys yra informacijos nepakankamumas ir skeptiškas vartotojų požiūris ị İSA, kuris labai svarbus apsisprendžiant dẻl pirkimo. Atsakingą vartojimą урас̌ riboja žemas vartotojų veiksmingumo suvokimas. Vartotojų naudojami informacijos šaltiniai tam tikra prasme turi įtakos suvokiamam kiekvieno sprendimo efektyvumo laipsniui. Informaciją, pateiktą socialinès atsakomybės ataskaitose, vartotojams dažnai sunku panaudoti priimant pirkimo sprendimus, svarstydami pirkimo alternatyvas jie retai tikslingai ieško informacijos apie İSA. Efektyvus būdas informuoti vartotojus apie gamintojų atsakingumą yra prekių ženklai ir specialios etiketės.

\section{Literatūra}

Adomaviciute, K. (2013). Relationship between utilitarian and hedonic consumer behavior and socially responsible consumption. Economics and management, Vol. 18, No. 4, p. 754-760.

Auger, P., Burke, P., Devinney, T. M., Louviere, J. L. (2003). What will consumers pay for social product features? Journal of business ethics, Vol. 42, No. 3, p. 281-304.

Boulstridge, E., Carrigan, M. (2000). Do consumers really care about corporate responsibility? Highlighting the attitude-behavior gap. Journal of Communication Management, Vol. 4, No. 4, p. 355-368.

Bray, J., Johns, N., Kilburn, D. (2011). An exploratory study into the factors impeding ethical consumption. Journal of business ethics, Vol. 98, No. 4, p. 597-608.

Castaldo, S., Perrini, F., Misani, N., Tencati, A. (2009).The missing link between corporate social responsibility and consumer trust: the case of fair trade products. Journal of business ethics, Vol. 84, No. 1, p. 1-15.

Cornelissen, G., Cojuharenco, I., Karelaia, N. (2011). One person in the battlefield is not a warrior: self-construal, perceived ability to make a difference, and socially responsible behavior. Barselona GSE, Working paper, No. 589, p. $1-34$.

Cotte, J., Trudel, R. (2009). Socially conscious consumerism: A systematic review of the body of knowledge. Network for Business Sustainability. Prieiga internete: http://nbs.net/fr/files/2011/08/NBS_Consumerism_SystRev.pdf.

D'Astous, A., Legendre, A. (2009). Understanding consumers' ethical justification: a scale for appraising consumers' reasons for not behaving ethically. Journal of business ethics, Vol. 87, No. 2, p. 255-268.

Devinney, T. M., Auger, P., Eckhardt, G., Birtchnell, T. (2006). The other CSR: consumer social responsibility. Stanford social inovation review, Fall, p. 30-37. Prieiga internete: http://papers.ssrn.com/sol3/papers.cfm?abstract_ $\mathrm{id}=901863$.

Durif, F., Boivin, C., Rajaobelina, L., Lecompte, A. (2010). Socially responsible consumers: profile and implications for marketing strategy. International review research papers, Vol. 7, No. 6, p. 215-224.

Engel, J., Kollat, D., Blackwell, R. (1968). Consumer Behavior. New York: Holt, Rinehart and Winston.

Fontenelle, I. A. (2010). Global responsibility through consumption? Resistance and assimilation in the anti-brand movement. Critical perspectives on international business, Vol. 6, No. 4, p. 256-272.

Francois-Lecompte, A., Roberts, J. A. (2006). Developing a measure of socially responsible consumption in France. Marketing management Journal, Vol. 16, No. 2, p. 50-66.

Freestone, O. M., McGoldrick, P. J. (2008). Motivations of the ethical consumer. Journal of Business Ethics, Vol. 79, No. 4, p. 445-467.

Gonzalez, C., Korchia, M. (2009). How do socially responsible consumers consider consumption? An approach with the free associations method. Reserche et applications en marketing, Vol. 24, No. 3, p. 25-41.

Kozar, J. M., Connell, K. Y. H. (2013). Socially and environmentally responsible apparel consumption: knowledge, attitudes and behaviors. Social responsibility journal, Vol. 9, No. 2, p. 315-324.

Living planet report 2012: biodiversity, biocapacity and better choices. (2012). Prieiga internete: file://C:/Users/vytautas.juscius/Downloads/1_lpr_2012_online_full_size_single_pages_final_120516.pdf

Living planet report 2014: biodiversity, biocapacity and better choices. (2014). Prieiga internete: http://www.wwf.de/ fileadmin/fm-wwf/Publikationen-PDF/WWF_LPR_2014.pdf

Marin, L., Ruiz, S. (2007). „I Need You Too!“ Corporate identity attractiveness for consumers and the role of social responsibility. Journal of business ethics, Vol. 71, No. 3, p. 245-260. 
Oberseder, M., Schlegelmilch, B., Gruber, V. (2011). Why don't consumers care about CSR? A qualitative study exploring the role of CSR in consumption decisions. Journal of business ethics, Vol. 104, No. 4, p. 449-460.

Papaoikonomou, E., Ryan, G., Valverde, M. (2011). Mapping ethical consumer behavior: integrating the empirical research and identifying future directions. Ethics and Behavior, Vol. 21, No. 3, p. 197-221.

Ozkan, Y. (2009). The effect of some demographic characteristics of Turkish consumers on their socially responsible consumption behaviors. World applied sciences journal, Vol. 6, No. 7, p. 946-960.

Pedregal, V., Ozcaglar-Toulouse, N. (2011). Why does not everybody purchase fair trade products? The question of the fairness of fair trade products' consumption for consumers. International journal of consumer studies, Vol. 35, No. 6, p. 655-660.

Roux, C., Nantel, J. (2012). Conscious consumption and its components: An exploratory study. Advances in consumer research, No. 36, p. 903-904.

Schaefer, A., Crane, A. (2005). Addressing sustainability and consumption. Journal of macromarketing, Vol. 15, No. 1, p. $76-92$.

Smith, N. C. (2007). Consumers as drivers of corporate responsibility. The Oxford Handbook of Corporate Social Responsibility, p. 281-302. Oxford University Press Inc., NY.

Smith, N. C. (2003). Corporate social responsibility: not whether, but how? Center for marketing working paper. London Business School: April 27, 2012. London. Prieiga internete: http:/www.london.edu/facultyandresearch/ research/docs/03-701.pdf

Valor, C. (2008). Can consumers buy responsibly? Analysis and solutions for market failures. Journal of Consumer Policy, Vol. 31, No. 3, p. 315-326.

Valor, C. (2005). Corporate social responsibility and corporate citizenship: towards corporate accountability. Business and society review, Vol. 110, No. 2, p. 191-212.

\title{
SOCIALLY RESPONSIBLE CONSUMPTION：INCENTIVES AND LIMITATIONS
}

\author{
Vytautas Juščius, Deimantė Maliauskaitė \\ Klaipéda University (Lithuania)
}

\section{Summary}

The purpose of the article is to identify the key factors influencing socially responsible consumption and the reasons why consumers do not choose products of socially responsible companies. The article highlights two dimensions of socially responsible consumption: environmental dimension (avoidance to buy products that have a negative impact on the environment) and public dimension (avoidance to buy product of companies who have a negative impact on the welfare of the public). Consumer decisions when purchasing goods are more selfish than justified in the public interest. This is why socially responsible consumption is motivated when users see the benefits for themselves. Users almost always give priority to products with better functional features.

An analysis of the literature proves that corporate social responsibility (CSR) is not the dominant criteria in making purchase decisions of consumers. CSR is less important than the other purchase criteria such as price, quality, reliability, customer service, product warranty period, etc. The main reasons, which restrict socially responsible consumption are misconception of consumers, the perception that they have not much power to solve global problems, as well as lack of income, education and information about socially responsible consumption.

KEY WORDS: corporate social responsibility, socially responsible consumption, consumer behavior.

JEL CODES: M140, M310, L200, A130. 